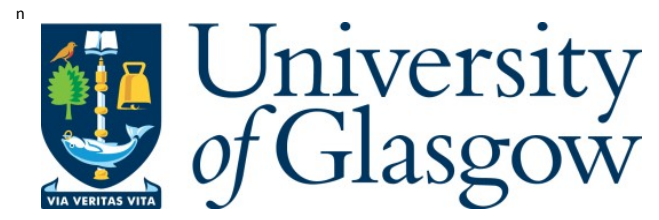

Smith, D. J (2016) Estonia: a model for interwar Europe? Ethnopolitics, 15(1), pp. 89-104.

There may be differences between this version and the published version. Y ou are advised to consult the publisher's version if you wish to cite from it.

http://eprints.gla.ac.uk/112462/

Deposited on: 23 December 2015

Enlighten - Research publications by members of the U niversity of Glasgow http://eprints.gla.ac.uk 


\section{ESTONIA: A MODEL FOR INTERWAR EUROPE?}

David J. Smith

University of Glasgow

ABSTRACT. W hile Estonia's 1925 Law on Cultural Self-Government for National Minorities is often cited as a rare functioning example of Renner and Bauer's non-territorial autonomy scheme, there has until recently been comparatively little research on how the law operated in practice. This article analyses the institutions of German and J ewish minority self-government established in inter-war Estonia, arguing that (prior to the eclipse of democracy in 1934, at least) these possessed considerable depth and authoritative competence in the area of cultural and educational policy. Cultural autonomy did not resolve all outstanding points of division between state, majority and (in particular) Baltic German minority; nevertheless, it played a positive role in the regulation of ethnonational tensions. Even less well-known is the international resonance of this unique law, which transnational minority activists argued should serve as a general model for the regulation of minority disputes. The League of Nations rightly questioned this claim, and the non-territorial autonomy model was scarcely applied beyond the Baltic region during the 1920s. However, it is still instructive to revisit the 1925 law today, at a time when several post-communist states have adopted minority rights legislation based on similar principles.

\section{Introduction}

The democratic Estonian Republic of 1918-1934 is widely acknowledged as one of the rare historical cases in which Renner and Bauer's model of minority non-territorial autonomy was successfully implemented in practice (Aun, 1950; Coakley, 1994). Estonia's February 1925 Law on Cultural Self-Government for National Minorities (Eesti Vabariigi Vähemusrahvuste kultuuromavalitsuse seadus) allowed spokespersons for the German, Russian and Swedish minorities and other ethnonational groups numbering more than 3,000 the right to establish public-legal corporations of persons, constituted on the basis of voluntary enrolment by citizens on a national register. This register served as the voter list for electing a Cultural Council of the relevant minority, which could in turn vote to establish executive institutions with responsibility for schooling and other cultural matters across the entire territory of the state. As public-legal bodies, the organs of minority self-government were entitled to levy taxes for cultural purposes on those citizens enrolled on the register. These supplemented income obtained from central and local government and other sources.

Estonia's February 1925 law went far beyond the more limited minority rights provisions adopted by most other newly-created states of Central and Eastern Europe at this time, and (not least in its use of the Renner and Bauer model) could be described as unique in the Europe of the day. Provisions elsewhere in Central and Eastern Europe were largely based on treaties signed by the new states under the terms of the post-F irst World War peace 
settlements brokered by the victorious Allied Powers. Under these treaties, persons belonging to national minorities were to be guaranteed equal rights as citizens, as well as additional positive rights pertaining to the preservation and practice of their distinct culture. Among the latter were the right to state-funded primary education in one's native language, as well as the right to establish and run private educational, charitable, religious and social institutions. There was, however, no scope to establish publicly funded institutions of minority self-government. The treaties were to be upheld by the minority protection system of the League of Nations. In practice, however, this granted individual state governments an effective right of veto in all questions pertaining to the treatment of minorities. The three Baltic States were not subject to minority treaties, since they were formed independently of the post-war peace settlements. In this regard, Latvia also adopted far-reaching provisions for minority autonomy in the area of schooling, but this was not done on the basis of the Renner and Bauer model. Lithuania also conducted a short-lived experiment with nonterritorial autonomy for its J ewish minority at the start of the 1920s, but this was curtailed already prior to the onset of authoritarian nationalist rule in December $1926 .^{1}$

The Estonian Cultural Autonomy Law of 1925 was promptly implemented by representatives of the German (November 1925) and J ewish (May 1926) minorities, several of whom subsequently went on to play a prominent role in the European Nationalities Congress - a transnational non-governmental organisation founded in October 1925 which lobbied for a reform of League of Nations minority protection procedures and advocated non-territorial autonomy as a general model for minorities living in Central and Eastern Europe and beyond (Hiden \& S mith, 2006). Such appeals never found a broad resonance in the context of interwar Europe. Yet, the Estonian experience of the 1920s has arguably acquired a new relevance today, at a time when several states of post-communist Central and Eastern Europe have adopted minority rights legislation based (at least nominally) on the principle of non-territorial autonomy. ${ }^{2}$

For all of the interest in the 1925 law, however, it is only recently that scholars have turned their attention to analysing how it actually operated in practice, as opposed to debating the reasons for its adoption (Laurits, 2008; Smith \& Hiden, 2012). The present article builds on my own previous work in this area. After giving a brief overview of the ethnonational structure in inter-war Estonia and a background to the introduction of the law, it will analyse the nature and functioning of the institutions to which it gave rise, with particular reference to their non-territorial character, the degree of autonomy they conferred and their role in the regulation of ethnonational tensions. 


\section{The Ethnonational Structure of Inter-War Estonia}

The Republic of Estonia was declared in February 1918, obtained international legal recognition of its independence during 1920-22 and maintained its first period of existence as a fully sovereign state until J une 1940, when it underwent military occupation and forcible annexation by the USSR. The first census in independent Estonia, carried out in 1922, counted just over 1.1 million inhabitants. As well as being small in population, Estonia was amongst the most ethnonationally homogeneous of the successor states that emerged out of the collapse of the Central and East European empires after the First W orld War. Inhabitants professing Estonian nationality made up $87.6 \%$ of the population; of the remainder, 8.2\% declared themselves to be Russian, 1.7\% German and 0.7\% S wedish by nationality. The remaining fraction consisted of a number of numerically very small minorities, of which the largest was the J ewish $(0.4 \%$ of the total population) (Statistics Estonia, 2011).

Estonia's ethnonational minorities were therefore numerically small in size, and they were to a significant extent also territorially dispersed in respect of their settlement. Of the aforementioned groups, only the Russian and the Swedish displayed any degree of territorial compactness. The bulk of the local ethnic Russian population was concentrated in two rural regions: an area of religious Old Believer settlement on the western shores of Lake Peipsi (dating from the seventeenth century), and eastern border districts that were appended to the Estonian Republic under a 1920 peace treaty with Soviet Russia and which had previously formed part of neighbouring gubernii of Russia rather than the historic Baltic provinces of Estland and Livland. The remainder were mainly in larger towns and cities such as Tallinn, Tartu and Narva. The laws on public primary schools (May 1920) and public secondary schools (gymnasiums) (December 1922) adopted by the Estonian Republic after independence allowed for the creation of new minority language schools (or separate classes within a school) in a particular municipality, if it contained at least 20 children whose mother tongue was not Estonian. ${ }^{3}$ This policy of public recognition allowed for the creation of a network of state-funded Russian-language schools in the above-mentioned rural districts and the larger towns. Furthermore, in those municipalities where a particular minority made up more than $50 \%$ of the population, the given minority language could be used alongside Estonian as an official language of local government.

Spokespersons for the Russian minority in inter-war Estonia were generally satisfied with these provisions when it came to questions of cultural rights. Some members of the urban Russian elite-most notably the Tartu University Law P rofessor Mikhail Kurchinskii-argued strongly for the implementation of cultural autonomy, on the grounds that this would allow for 
fuller control over issues such as teacher recruitment and curriculum design. Overall, however, the Russian elite was too politically divided and the bulk of the population too impoverished and lacking in social capital to allow for coalescence around an autonomy agenda (S mith, 1999). Similar circumstances applied in the case of Estonia's small and historically long-standing Swedish minority, which earned its living mainly from fishing and farming and was concentrated in coastal areas of western and northern Estonia and on several offshore islands. Only in four municipalities within these areas did ethnic Swedes constitute an overall majority of the population (Alenius, 2003, p. 36). This limited the scope for use of Swedish as a local language of administration alongside Estonian. Nevertheless, the provisions of the law on education allowed for the creation of 19 Swedish-language primary schools, a gymnasium and two vocational training schools during the inter-war period. The option of cultural autonomy for the S wedish minority was considered at this time but was never implemented, largely because of economic considerations and a low level of ethnically-based political mobilisation amongst local Swedes. ${ }^{4}$

The position was, however, very different when it came to the German minority. Estonia's ethnic German population was not only numerically small, but also highly dispersed: there was no local municipality where Germans made up a majority of the local population, and only in two cases (out of a total of 410 municipalities) did they constitute more than $10 \%$ of the total population (Coakley, 1994, pp. 302-3). Despite their small numerical size, Germans in inter-war Estonia were very much a high-status group: under various jurisdictions, they had exercised political and economic power in the Baltic territories for 700 years prior to 1918, through a rigid estates-based system that only began to dissolve under the impact of modernisation during the late nineteenth and early twentieth century. At the time of Estonia's independence, the small group of German nobles still owned more than half of the agricultural land, while Germans also played a disproportionately large role within the urban economy. Until challenged by the emergence of the Estonian national movement and (later) the Russification policies of the tsarist regime during the mid- and late nineteenth century, German was the main language of education and culture within the Baltic provinces, and cultural Germanisation was a prerequisite for those members of the predominantly Estonian peasant class who sought social advancement.

This state of affairs changed dramatically during 1917-20, when German-dominated political structures were finally abolished, the noble estates were redistributed to the landless rural population and local Germans were assigned a status of national minority within the new Estonian Republic. In the early 1920s, only six of the pre-existing German schools in Estonia (located in the capital Tallinn, the second city Tartu and the village of Musjas (near Võru)) were recognised as public schools entitled to funding from the state (Laurits, 2008, pp. 105- 
6). Together, the schools in these settlements catered for $36 \%$ of the 3,739 pupils in Estonia receiving German-language education in 1925. The remainder attended a network of 19 private schools which were inadequately financed, despite charging relatively high fees and receiving subsidies from Germany and from local German community organisations (Smith \& Hiden, 2012, p. 52; see also Alenius, 2003, pp. 246-7). Against this background, members of the small and socio-politically cohesive German former elite were quick to formulate demands for self-government along non-territorial lines, which they hoped would allow for greater rationalisation of German-language education. Some German leaders framed autonomy in terms of Renner and Bauer's original conception, seeing this as the only viable way of ensuring the continued long-term reproduction of German language and culture within the framework of the newly-independent Estonia. Other more conservative elements, however, ascribed a more substantial role to autonomous structures based on corporatist thinking inherited from the tsarist period and were reluctant to concede the shift in the ethnonational balance of power that had occurred with independence (S mith \& Hiden, 2012, pp. 36-37).

Spokespersons for Estonia's numerically small J ewish minority similarly displayed a firm commitment to preserving its distinct identity through autonomy, albeit on the basis of an altogether different historical experience. In this regard, the creation of an independent Estonia opened the way to fuller civil rights for the J ewish population and the establishment of a private J ewish elementary school (initially teaching in R ussian) during 1919 and a secondary school in 1923. A Congress of Estonian J ewish Congregations held in 1919 came out strongly in favour of non-territorial autonomy, which had formed the basis for the political programme of the socialist Bund and J ewish diaspora parties and organisations active in the pre-revolutionary Baltic provinces of the Tsarist Empire (Weiss-W endt, 2008, p. 97; Smith \& Hiden, 2012, p. 33). ${ }^{5}$ W hile the J ewish community was unable to secure representation at Estonia's Constituent Assembly held in 1919, its leaders subsequently liaised with Baltic German deputies who presented an initial bill on non-territorial (or 'cultural') autonomy to the country's parliament (Riigikogu) in the spring of 1921.

\section{Background to the Introduction of Cultural Autonomy}

W hile the cultural autonomy law was finally adopted only in 1925, it represented the fulfilment of undertakings made during the formative years of the Estonian Republic during 1918-20. The declaration of independence adopted in February 1918 had taken the form of a manifesto to 'all the peoples of Estonia'. This spirit was reaffirmed by the constitution adopted in 1920 (drawn up in the name of the 'people of Estonia', Eesti rahvas) rather than ethnic Estonians (Eesti rahvus), which enshrined the freedom of each individual to determine 
his or her nationality (ethnicity), the right to education in one's native language and the right of national minorities to establish autonomous cultural institutions (Eesti Vabariigi põhiseadus, 1920).

Early state-building took place against the background of a three-way military struggle for power, in which an Estonian provisional government ultimately prevailed against the competing ambitions of the Bolsheviks and German military units that remained stationed in the Baltic following the Western armistice of 1918. These events culminated in a February 1920 peace treaty with Soviet Russia, which marked the first instance of full de jure recognition for the new republic. While the Western Allies extended de facto recognition in 1918 and lent support to the fledgling Estonian state at key junctures in the conflict, they exhibited little intrinsic interest in Estonian independence per se prior to the final defeat of White forces in the Russian Civil War; full de jure recognition from the West and membership of the League of Nations was not forthcoming until 1921.

According to one interpretation of Estonian state-building, the generous provisions for minority rights adopted during 1918-20 were driven primarily by considerations of Realpolitik. By this reading, the military struggle of these years dictated strategic concessions to minorities in an effort to rally all inhabitants behind the cause of independence; once this goal had been achieved, Estonia's precarious geopolitical position between Germany and Soviet R ussia ensured that the same line was continued. As several authors have argued, however, considerations of realism do not in themselves suffice to explain why the Estonian authorities proved so receptive to the autonomy claims voiced by Baltic German representatives in particular. For these scholars, the context of Estonia's formationindependent of Western-brokered peace settlements elsewhere in Central and Eastern Europe-allowed space for previous multinational federalist thinking to be carried over from pre-revolutionary and revolutionary Russia into a new setting. In this regard, the idea of cultural autonomy had attained broad currency not only within Baltic German and J ewish political circles, but also amongst a large part of the ethnic Estonian political elite, which had become well versed in the thinking of Renner and Bauer through its participation in the democratising movements of 1905-17. This support for cultural autonomy cut across Estonian party lines, finding adherents on both the Left and the Right. ${ }^{6}$

Thus, while autonomy proposals first brought to the Estonian parliament ( $R$ iigkogu) in 1921 encountered stiff resistance from more nationalistically-minded Estonian representatives over the next four years, they enjoyed the backing of such influential figures as Konstantin Päts, a co-founder of the Estonian Republic who served as Prime Minister at crucial junctures in the cultural autonomy debate during 1921-22 and 1923-24. While Päts and 
others were clearly driven at least partly by external considerations (not least the desire to ensure the goodwill of the League of Nations in the face of international attacks by dispossessed Baltic German landowners), Estonia's commitments to the League in no way obliged it to go beyond the more limited minority protection framework applied to other states of the region and introduce a full system of cultural autonomy. Following its entry to the League, Estonia was obliged to sign a minority declaration (in September 1923). However, in so doing it argued successfully (and, it must be said, with justification) that its existing policies in this area were already in accordance with the general principles of the post-war minority treaties that were in force elsewhere (Crols, 2005, pp.189-90). Indeed, this fact was later invoked by domestic opponents of cultural autonomy as an argument against introducing a more far-reaching system of cultural autonomy (Alenius, 2003, p. 329). An abortive attempt by local communists (with Soviet backing) to stage an armed uprising in December 1924 is often cited as an additional factor pushing the Estonian parliament to approve the cultural autonomy law. As historian Kari Alenius (2007, pp. 452-5) has demonstrated, however, the political path to this decision had already been cleared well before the December coup: at a meeting held in March 1924, for instance, J aan Tõnisson (head of the liberal nationalist Estonian People's Party and the most outspoken opponent of minority autonomy during 1921-24) gave his backing to the law in return for an agreement by Baltic German leaders that the competences of autonomous institutions would be limited to schooling and culture. This was subsequently confirmed and reinforced by further amendments to the draft law which removed social welfare issues and church affairs from the sphere of competences held by minority self-governments.

\section{The Structure and Operation of Cultural Autonomy}

The legislation adopted in February 1925 was originally intended as a temporary framework that would allow for the organisation of minority self-government pending the entry into force of a special law laying out more detailed provisions for the operation of autonomous institutions. No such law was, however, adopted; as a consequence, the 1925 act provided the foundation for the creation and development of German and J ewish agencies of cultural self-government (CSGs) during the late 1920s and early 1930s. In both cases, the act provided for the establishment of a Cultural Council (parliament-with a minimum of 25 and maximum of 60 members), elected by citizens who had declared their affiliation to the relevant minority and voluntarily enrolled on a national register. The Cultural Council then elected a Cultural Government, which functioned as the executive arm of autonomy. These organs of self-government were based in the Estonian capital Tallinn and had a remit extending to the territory of the republic as a whole. This included the right to establish 
cultural curatoria in individual counties and towns, which would manage issues arising at the local level. Under Article 1, CSGs were made subject to the same legislative framework as that governing existing territorially-based local authorities. Thus, despite having their own separate public-legal existence, they were subordinate to the Interior Ministry of the Estonian Republic, with the CSG president deemed equivalent in status to an Interior Ministry department head (Laurits, 2008, p. 146). ${ }^{7}$

The law gave minority CSGs the power to organise, manage and supervise public and private minority language educational institutions, and to manage institutions and enterprises dealing with other cultural matters relevant to the minority in question (Article 2 ). ${ }^{8}$ In carrying out these tasks, CSGs had the right to issue ordinances that were legally binding upon those who had signed up to the national register of the minority concerned. Having first determined the extent of the minority public school network through a central government-approved agreement with town and county councils, CSGs were to assume responsibility for the relevant schools and the funding assigned to these schools by state and local government. Further sources of finance specified under the law included public funding earmarked for cultural activities, donations and bequests, income from property or enterprises, and cultural taxes levied on those belonging to the national register. The base and level of such taxation was to be set by the Cultural Council of the CSG in accordance with its budget and was to be approved by the Interior Ministry and the Ministry of Education. In the sphere of education (which constituted the central pillar of their activity), the competence of CSGs extended to determining the allocation of resources and the general character (academic or vocational) of minority schools, drawing up school curricula and recruitment of staff. Decisions in this area had to be ratified by the Ministry of Education, which exercised broad oversight in areas such as the selection of school textbooks.

National minority representatives seeking to establish cultural autonomy had in the first instance to present an application to the Estonian government. Once this had been approved, the next step was to draw up a national register as a basis for elections to a Cultural Council. This was done by collating a list of all citizens of the Estonian Republic who were registered as bearing the relevant ethnic nationality. This list was then made available for public scrutiny for a period of two months. Anyone not wishing to be included could apply to have his or her name removed. Conversely, any citizen wishing to be added to the register could do so by opting for the relevant ethnic nationality and requesting inclusion. In order to proceed to an election, the number of persons registered had to be not less than $50 \%$ of the total size of the given minority as established under the most recent census ( $S$ mith $\&$ Hiden, 2012, pp. 46-8). The cultural autonomy law provided for elections to a Cultural Council every three years; if, in the intervening period, the number of persons on the register fell below 
$50 \%$ of the census total (or if the overall numerical size of the minority fell below 3,000 ), central government had the right to abolish the Council. For elections to be valid, at least $50 \%$ of those enrolled on the register had to cast their votes.

The system can be illustrated by using the example of the German Cultural Council elected in October 1925. The Estonian census of 1922 had recorded 11,989 persons of voting age bearing German ethnic nationality. After an application to set up a German national register had been approved by the government in J une 1925, representatives of the German community were therefore required to register just less than 6,000 citizens in order to hold elections. In the event they were able to register 11,562, a fact which attests at least in part to the continued fluidity of ethnic boundaries in Estonia in the 1920s. When it came to the elections, one or more lists of candidates were drawn up in each of the ten county-level constituencies used for state parliamentary elections. Voters in a given constituency then ranked the candidates, with the overall number of mandates per constituency determined according to the size of the local German population. On this basis, $67 \%$ of registered voters turned out in October 1925 to elect 38 members from 64 candidates (S mith \& Hiden, 2012, pp. 48-9). At its inaugural meeting the following month, the German Cultural Council voted unanimously in favour of adopting cultural autonomy. A five-member executive was appointed and departments for education, culture, sport and youth affairs, and finance were established, along with a permanent secretariat to oversee the local cultural curatoria established in each of the nine electoral constituencies outside the capital. Similar procedures were followed to elect the 25-member J ewish Cultural Council convened in May 1926 , after $71 \%$ of those enrolled on the J ewish national register had turned out to vote (W eiss-W endt, 2008, p. 97).

Education was far and away the most important sphere of activity for the minority CSGs. In this respect, the first priority of the German administration established in November 1925 was to bring both private and public schools within a single unified network that would enable every German child in Estonia to obtain free elementary education in his or her mother tongue. Private schools were incorporated within a matter of months, while the formal transfer of public schools from local authority jurisdiction to that of the CSG took place at the start of the 1926-27 school year. With autonomy in place, the state finally consented to transfer a number of private German-language schools to the public sector during 1928, making them eligible for state support. It was only in that same year, however, that agreement was finally reached on the basis and extent of the funding to be provided by local authorities. In this regard the German CSG worked on the basis that the proportion of the education budget allocated to German schools should be calculated on the basis of number of pupils enrolled and the number of classes. The local authorities, however, argued 
(ultimately unsuccessfully) that the sum should be determined according to the ratio between Germans enrolled on the national register and the overall local population of the municipality in question (S mith $\&$ Hiden, 2012, pp. 52-3). These short-term financial uncertainties hastened the introduction of a system of self-taxation, which can be considered amongst the most significant achievements of the CSG during its first term of office. Taxation took the form of a compulsory levy, graduated according to income, on all adult members of the German national register who were in employment.

The successful implementation of this tax system during 1926-30 was one factor that allowed for considerable financial rationalisation within the context of a new unified and expanded school network. Under this framework, all pupils in German-language elementary schools benefitted from free education; in the case of private schools, the fee income thus forfeited was covered by subventions from the CSG, which also set the level of fees payable in such schools once pupils moved beyond the compulsory phase into higher classes. Here, parents who were enrolled on the national register were entitled to reduced fees. A report by the German CSG from 1928 showed that, even taking account of self-taxation, parents enrolled on the national register made an overall saving under this system. The development of J ewish minority schooling exhibited a similar pattern following the introduction of cultural autonomy in 1926 (S mith \& Hiden, 2012, pp. 55-6). The existing J ewish schools in Tallinn were integrated into the state network, and a further primary school (in the southern town of Valga) and secondary school (in the second city, Tartu) were established. On this basis, the proportion of J ewish pupils studying in schools controlled by the J ewish CSG increased from $33 \%$ in the mid-1920s to $56 \%$ by 1935 (S mith \& Hiden, 2012, p. 61).

\section{Non-Territorial Autonomy and Inter-Ethnic Relations: An Assessment}

How successful, then, was the system of non-territorial autonomy in creating genuinely representative minority institutions and resolving sources of ethnonational tension? That the new institutions did not enjoy totally unquestioned legitimacy in the eyes of the communities they purported to represent can be seen most clearly in the case of the J ewish CSG, which could not easily accommodate the diverse cultural orientations found within this small yet internally heterogeneous minority. In this regard, a vote by the Zionist majority within the newly-established Cultural Council to make Hebrew a language of instruction at the J ewish Secondary School in Tallinn proved contentious, leading a number of parents to apply to withdraw their children from the school and prompting the creation of a separate Yiddishlanguage private school, which the CSG refused to incorporate into its school network (Smith \& Hiden, 2012, pp. 61-2; Weiss-Wendt, 2008, p. 91). When the CSG was later given the exclusive right to decide whether members of the national register could transfer their 
children out of the CSG network to either private J ewish or to non-J ewish schools, a number of parents simply withdrew from the register (S mith \& Hiden, 2012, pp. 62-3).

Such internal dissension (while not entirely absent) was less apparent in the case of the German minority, which was more socio-politically cohesive and for which language served as a more obvious unifying marker of identity than it did in the J ewish case. W riting at the start of the 1930s, the editor of the main German-language newspaper in Estonia claimed that cultural autonomy now embraced ' 100 per cent of Germans' and was largely viewed in positive terms, despite obvious shortcomings arising from the framework character of the 1925 law (de Vries, 1930). Perhaps the main shortcoming-as already noted-could be seen to lie in the absence of clearly-defined provisions for continued public funding of schools, which had proved to be a source of friction between the German CSG and municipal governments during the early period of autonomy. These issues had, however, been largely resolved by the end of the first three-year term of the CSG, leading its Chairman to assert in his concluding report that the risk of embarking on self-government had been well worth taking. ${ }^{9}$ In the course of 1925-28, some elements within the German community also expressed dissatisfaction over what they saw as excessive continued regulation of German schools by the Ministry of Education. The Secretary of the German Cultural Council, however, attributed such complaints to unrealistically high initial expectations, and a consequent failure to grasp that what Germans had received was 'selfgovernment on the same basis as local authorities, in no way full autonomy, that is to say an administration completely independent of the state. ${ }^{10}$

This characterisation seems essentially correct, for the 1925 law gave ethnonational minorities the possibility for substantial (though not absolute) functional autonomy in the sphere of culture, within what was otherwise a unitary nation-state structure. As outlined earlier in this article, the state also accorded far-reaching public recognition to the cultures of the non-autonomous Russian and Swedish minorities, whose representatives had a foothold in local government. An electoral law based on proportional representation also meant that nearly all of the largest minorities sent deputies to the state parliament. In practical terms, however, decision-making in spheres other than culture remained in the hands of the ethnic Estonian majority; each of the largest minorities had a National Secretary within the Ministry of Education, but minority members were otherwise under-represented within the state bureaucracy. Nor was there any specific forum geared to promoting dialogue between the different nationalities living within the state.

Overall, it seems clear that the introduction of cultural autonomy had a positive impact on inter-ethnic relations during the late 1920s. German leaders declared themselves to be 
generally satisfied with the arrangement, while the provisions for the J ewish minority were widely acknowledged as the most far-reaching in Europe at that time. ${ }^{11}$ Satisfaction was also voiced by numerous Estonian state officials, while several former opponents of the law now conceded that, in practice, it had not led to the formation of 'states within a state' (Smith \& Hiden, 2012, p. 69). For all this, however, cultural autonomy could not in itself alleviate all sources of tension between the state and minorities, especially when it came to the historically problematic relationship between Estonians and Germans. Continued frictions were apparent, for instance, in the area of church affairs (slated for inclusion within the scope of autonomy under original proposals presented by German representatives), where the 1927 transfer of Saint Mary's Cathedral in Tallinn from the German to the Estonian consistory of the Evangelical Lutheran Church aroused widespread opposition within the German community. By the same token, Russian parliamentary deputies returned from the areas of compact ethnic R ussian settlement in eastern Estonia also frequently complained about a lack of fiscal transfers to these newly-incorporated regions and the inadequacies of land reform there (S mith, 1999).

More broadly, the overlapping ethnic and socio-economic cleavages inherited from the tsarist Russian empire remained a significant obstacle to efforts to construct an overarching state community embracing all national groups. In this regard, the more far-reaching aspirations that some sections of the German elite had held with regard to autonomy betrayed in many instances a continued self-understanding as a superior 'caste apart' that should rightfully exercise a leading role within local society and in the Baltic region as a whole. From the standpoint of Estonian nationalists, meanwhile, the land redistribution of 1920 only went some way to redressing long-standing socio-economic inequalities between different groups: the leading role that Germans continued to exercise within the professions and the urban economy meant that the latter were resented as an economically dominant minority. Continued criticism was also voiced regarding the allegedly privileged position enjoyed by German-language schools, which typically had smaller class sizes compared to their Estonian-language equivalents and, as such, carried continued appeal for ethnically mixed Estonian-German families as well as those from other minority groups. Nationalist voices on both the Estonian and the German side were given additional impetus by the onset of the Great Depression and the rise to power of Hitler in Germany. From this point onwards, institutions of German cultural self-government were increasingly viewed as a potential conduit for Nazi influence, not least because of the significant external subsidies that Germany had provided annually following the establishment of autonomy in the mid-1920s.

Not surprisingly, the worsening economic and political climate carried adverse implications for the practice of German cultural autonomy. Already in the late 1920s, one of the key 
pillars of minority autonomy - the freedom of each citizen to determine his or her ethnic nationality- had been undermined by a new law that prohibited persons of Estonian descent from opting for German nationality. A more restrictive interpretation of the cultural autonomy law had also become apparent on the part of the Interior Ministry, which, while not empowered to annul decrees issued by the CSGs, nevertheless asserted its right to block their implementation should they be deemed incompatible with more general state legislation (S mith \& Hiden, 2012, pp. 93-4). Archival documents from 1932-33 suggest that the Ministry of Education had by that time similarly begun to engage in fuller scrutiny of the content of history textbooks used in German-language schools. Simultaneous press articles alleging a growing influence of 'Hitlerism' within these institutions were vigorously countered by the German CSG, where leading figures such as W ilhlem von Wrangell (Chair of the Cultural Council) were known to harbour a dislike of National Socialism (S mith \& Hiden, 2012, pp. 957). Nevertheless, when a local Nazi sympathiser briefly captured the leadership of Estonia's main Baltic German political party in late 1933, the government temporarily suspended the activity of the CSG, with some Estonian politicians claiming that this had become little more than a 'department of the German state within Estonia' (Laurits, 2008, pp. 87-8).

'Nationalising' state projects and policies within Estonia acquired greater momentum after March 1934, when, invoking the deteriorating international environment and the threat from the Estonian Radical Right, acting President Konstantin Päts suspended parliamentary democracy and proceeded to establish an authoritarian presidential regime. Päts had of course been one of the key Estonian advocates of minority non-territorial autonomy during the early-mid 1920s; in line with this perspective, he did not abolish existing cultural autonomy institutions outright, but rather incorporated them within a corporatist system of government. While this provided at least some continued channels for dialogue between CSG leaders and the government, the substance of minority autonomy was in practice greatly reduced. Indeed, a new constitution introduced in 1938 made reference not to cultural autonomy but only to cultural self-administration. Also absent from the constitution was any reference to the right to education in one's mother tongue. Minority language schools continued to operate, but teaching within them was to be conducted both in the minority language and in Estonian, 'on the basis of and within the limits prescribed by law' (S mith \& Hiden, 2012, pp. 101-3). The fact that Russian minority elites reactivated their efforts to attain cultural autonomy during the mid- and late 1930s suggests that the autonomously organised German and J ewish minorities fared slightly better under the new arrangements than those whose schools and cultural institutions were under direct control of central ministries and local authorities. Nevertheless, in a speech to mark the tenth anniversary of cultural autonomy in late 1935, the then Head of the German CSG made 
reference to a constant struggle against unfriendly decrees now emanating from the state bureaucracy. ${ }^{12}$ One such measure was a new law introduced during the previous year, which stipulated that all children with at least one ethnically Estonian parent were now required to attend an Estonian-language school, regardless of the family's wishes in this matter.

The shrinking space for minority autonomy and more general curtailment of democracy within Estonia during the 1930s was partly a reflection of domestic developments, not least growing popular disenchantment with an unstable parliamentary system of government that proved incapable of taking quick and decisive action to combat the effects of the Great Depression during 1929-32. The wider European turn towards nationalism and fascism, which found its own local manifestation in the form of the popular 'VAPS' (League of Freedom Fighters) movement suppressed by $P$ äts in 1934, also had a part to play, but so too did a deteriorating international environment in the Baltic Sea region. From 1933, Estonia and the other Baltic countries found themselves caught directly between the competing designs of an aggressive and expansionist Nazi Germany and a Stalinist USSR that was intent on attaining control over the western borderland territories that had formed part of Russia before 1918. In this respect, the agreement on spheres of influence that these two powers struck in August 1939 marked the final death knell for Estonia's inter-war experiment with cultural autonomy. While by no means all local Germans felt an affinity with Hitler's Germany, by the end of 1939 the vast majority opted for resettlement from Estonia to the Reich under the terms of the so-called Nachumsiedlung, seeing this as preferable to the prospect of living under Soviet rule. In the wake of this mass exodus, the structures of German CSG were formally dissolved at the end of 1939. J ewish cultural autonomy institutions remained in place, but were abolished in late 1940 following Estonia's annexation by the USSR.

\section{Conclusion}

The introduction to this collection has asked contributing authors to consider whether the arrangements in the case study they address are genuinely non-territorial, and to assess the depth of autonomy that they confer. In the case of inter-war Estonia, the non-territorial aspect appears clear-cut: although (as Renner and Bauer had envisaged under their original scheme) there was a territorial dimension to the establishment and administration of autonomy (for instance through the proportional allocation of seats on the basis of existing electoral constituencies and the establishment of county-level curatoria), the 1925 cultural autonomy law followed the principle of voluntary enrolment on a national register in order to create 'communities of persons' and to establish centralised institutions with a remit extending to the state territory as a whole. The law, moreover, was implemented by two 
dispersed minority communities which in neither case could draw upon any parallel, territorially-based structures of representation specific to the group.

When considering the degree of autonomy conferred by this arrangement, one obviously needs to distinguish between the periods before and after the authoritarian turn of March 1934. With regard to institutional depth, however, the 1925 law provided for a nondeconcentrated administration subject to central government veto. Under the measurement scale devised by Hooghe, Schakel and Marks (2008) and adapted by Coakley (2016) in the introduction to this collection, this would therefore represent a score of two points. In respect of scope, it would seem reasonable to claim that minority CSGs possessed authoritative competence in the area of cultural-educational policy, giving a score of one. This, at least, was the case during the period 1925-1934; thereafter, the practice appeared more consistent with symbolic recognition than it did with genuine autonomy. Under the heading of fiscal autonomy, a score of two would seem appropriate, as the CSG was able to determine both the base and the rate of taxes raised for cultural purposes from amongst those enrolled on the national register. Finally, the system can be seen to score two points under both headings related to representation, as the autonomously constituted minority had its own directly elected assembly which in turn appointed the executive arm of CSG. Overall, then, this would give a score of nine out of 15 according to the Hooghe-Marks-Schakel scale.

It therefore seems fair to characterise the 1925 cultural autonomy law (at least in its initial incarnation) as providing for a substantive variant of autonomy that was well-suited to the cultural and educational requirements of Estonia's numerically small and territorially dispersed German and J ewish minorities. As already noted, the arrangement was viewed positively by actors from both the minorities in question and the majority community during the 1920s; however, it did not definitely resolve all sources of ethnonational tension within what was otherwise configured as a unitary nation-state. To discuss issues related to 'shared rule' (such as level of representation within the state legislature, role of communities in codetermining national policy and distribution of revenues) falls largely beyond the scope of the current article and collection, which focuses rather on the dimension of 'self-rule'. Nevertheless, the Estonian experience of the late 1920s and early 1930s suggests that autonomy is only part of the equation when it comes to the management and accommodation of ethnonational cleavages, especially where boundaries are strongly politicised and there remain considerable power imbalances between different groups.

It should also be remembered that the option of cultural autonomy was not taken up by two of the 'historic' national minority communities (the Russian and the Swedish) deemed eligible for this under the 1925 law. This was undoubtedly due in part to the territorially concentrated 
nature of these minorities, and the fact that the Estonian legislation of the early $1920 \mathrm{~s}$ offered them public recognition and provided for considerable administrative decentralisation if not formal territorial autonomy. Another factor, however, was the lower level of political mobilisation, cohesion and resources upon which R ussian and $\mathrm{S}$ wedish minority activists could draw. The Swedish minority (and some elements of the Russian, such as the Peipsi Old Believer communities) were already highly acculturated and integrated within the majority societal framework. In the Russian case, key minority leaders such as Mikhail Kurchinskii argued strongly for cultural autonomy as something that would provide for a qualitatively higher level of recognition and self-rule. Others, however, remained unconvinced of the merits of this scheme, insisting not least that it might impose undue additional financial burdens on an already impoverished Russian rural population.

The unwillingness of the Russian and Swedish minorities to organise within the cultural autonomy framework served in turn to undermine the arguments of those who portrayed Estonia's law as a model for the wider inter-war Europe. In a move that coincided with the establishment of the German CSG in Tallinn, minority activists from across the continent gathered in Geneva in October 1925 to establish the European Nationalities Congress, a lobby group that pressed for a more generalised application of non-territorial autonomy as part of a reform of the League of Nations minority protection framework. It is no coincidence that many of the key leaders of the new Congress had previously worked within the unique political environment of the Baltic States. Mikhail Kurchinskii served as one of the Vice Presidents, while a Baltic German from Estonia, Ewald Ammende, served as General Secretary from 1925 until his death in 1936. It was Ammende who, at the seventh annual meeting of the Congress in 1931, pointed to the positive experience of cultural autonomy in Estonia over the previous five years and called upon the League of Nations to undertake a more thorough examination of the model to ascertain its possible utility elsewhere. The Minorities Secretariat of the League duly complied with this request, but was highly sceptical in its conclusions, noting that while cultural autonomy might be well-suited to the particular circumstances of the Baltic Germans, other eligible minorities in Estonia had not backed the arrangement. Moreover, it was claimed, spokespersons for German minorities elsewhere in Europe had expressed doubts about the viability of the model, while Congress leaders had failed to engage in a full and meaningful debate before advancing the proposal on behalf of autonomy. ${ }^{13}$

Part of the problem here lay in the fact that Congress leaders advocated non-territorial autonomy on largely idealistic grounds, as a catch-all alternative to territorially-based selfdetermination and-thereby-as a means of breaking the conceptual link between ethnicity and territory that formed such a potent obstacle to the achievement of a durable European 
peace. As already discussed in the case of Estonia, however, cultural autonomy could not necessarily be seen as a universally applicable panacea for resolving ethnonational disputes. The needs of the Russian minority in Estonia, for instance, arguably lent themselves to a more territorial mode of representation, at which point cultural autonomy would at best have served as a supplement rather than an alternative to such an arrangement. There were many other minority spokespersons in inter-war Europe who shared this view; the problem was that, in the context of the territorial disputes and continued nationalist frictions bequeathed by the peace settlements, territorial autonomy was deemed potentially threatening to state sovereignty and integrity.

More generally, one can say that the League of Nations and the larger Western powers remained deeply suspicious of any form of collective minority autonomy, territorial or nonterrritorial, arguing that this would lead inexorably to the formation of 'states within states'. In this regard, Ludvig Krabbe of the League Minorities Secretariat expressed the view that 'the development, in countries of mixed population, of a spirit of national tolerance and liberalism ... will become all the more difficult if a system of separatism in certain branches of the common life of the state becomes generalised'. ${ }^{14}$ While Krabbe's emphasis on tolerance and liberalism as prerequisites for ethnic peace have continued resonance for the contemporary ear, the political environment in today's Central and Eastern Europe appears far more propitious to non-territorial autonomy, as seen by the adoption of laws based on this model in several countries of the region during the past two decades. The nature and substance of these laws (not least Estonia's revised law on cultural autonomy, adopted in 1993) remain the object of much debate, as do the essential merits and applicability of non-territorial autonomy compared to other minority rights approaches (Bauböck, 2001; Nimni, 2005; Smith \& Cordell, 2008; S mith, 2013a, 2013b; Lagerspetz, 2014). Estonia's cultural autonomy law of 1925 has been cited as a precedent and example of good practice in various Central and Eastern European states that have adopted or debated variants of non-territorial autonomy over the past 25 years (see Smith \& Hiden, 2012, pp. 110-13; Kriszán, 2000, 2612). Most authors would agree, however, that the 1993 law adopted in Estonia, while often seen as a 'restoration' of its famous inter-war predecessor, is in fact a pale imitation, which was seemingly adopted largely for symbolic purposes (see Aidarov \& Drechsler, 2011; Poleshchuk, 2013; Smith 2014). W hatever standpoint one adopts within these debates, however, it is still timely and instructive to revisit the Estonian experience of the inter-war period.

\section{Notes}


1. On the nature and limitations of the treaties and the League system, see Crols, 2005 and S mith $\&$ Hiden, 2012, pp. 20-23. For a comparative discussion of the autonomy laws in the Baltic States and their operation, see S mith, 2005; S mith \& Hiden, 2012, pp. 26-69.

2. For a discussion of contemporary practices in the region based on non-territorial autonomy, see Osipov, 2013.

3. These laws, however, did not imply automatic state support for already existing schools teaching in languages other than Estonian (Alenius, 2003, p. 246).

4. 'Estlandssvenskarnas språkliga rättigheter I Estland'. 9/12 1974: Isberg, F ridolf, 1974. Landsmåls- och Folkminnesarkivet Uppsala, File no. 29727, p.8; see also Alenius, 2006 and Alenius, 2003, pp. 309-313 \& 368-370.

5. See also the Draft Statute for the J ewish Community in Reval (Tallinn), State Archive of Estonia, F.2297, N.1, S.1.

6. For a comprehensive overview of the debates surrounding the origins of inter-war cultural autonomy, see Alenius, 2003, $2004 \& 2007$; see also W eiss-W endt, 2008; Laurits, 2008; Smith \& Hiden, 2012, pp. 26-45; Piirimäe, 2012.

7. Unless stated otherwise, discussion of the details of the law and its individual articles contained in this section is based on the Estonian-language text of the 12 February 1925 law (Riigikogu poolt vastu võetud 'Eesti Vabariigi Vähemusrahvuste kultuuromavalitsuse seadus' ja üldkomisjoni seletuskiri), reproduced in Laurits, 2008, pp. 266-270.

8. This article stated that questions of welfare relating to a minority would be regulated according to a separate law, though no such law was ever forthcoming.

9. Protokolle des 1 deutschen Kulturrats, 1 November 1925-22 October 1928, $\mathrm{Nr} 13,22$ October 1928. State Archive of Estonia F.85, N.1, S.66.

10. Protokolle des 1 deutschen Kulturrats, 1 November 1925-22 October 1928, Nr 10, 4 J uly 1927. State Archive of Estonia F.85, N.1, S.66. Once again, the complaints voiced by some Germans can be seen in part as reflecting the mindset of a former ruling elite which resented the loss of the dominant position it had held prior to the First World War. Revealing here is the remark at the inaugural session by one former German noble, who expressed the view that if cultural autonomy were adopted, future generations would feel themselves not as Baltic Germans, but merely as part of a minority (cited in S mith \& Hiden, 2012, p. 50). In this regard, note also the claim by Weiss-Wendt (2008) that while the J ewish minority was by and large satisfied with cultural autonomy, many Germans saw it as a 'tactical retreat' that allowed them to cling to at least some vestiges of their former sovereignty. 
11. For instance, in $\mathbf{1 9 2 7}$ the J ewish National Fund in Palestine presented the Estonian government with a certificate of gratitude for its unparalleled act of granting cultural autonomy to the local J ewish minority; see Weiss-W endt, 2008, p. 98.

12. Cited in W.E., 1936, pp. 222-6.

13. For a full discussion of the Congress and its debates on non-territorial autonomy, see Hiden \& Smith, 2006; S mith \& Hiden, 2012, pp. 70-91.

14. 'L'autonomie culturelle comme solution du problème des minorités. Note de M.Krabbe au date du 18 Nov 1931', League of Nations Archive R.2175-4-32835.

\section{References}

Aidarov. A. \& Drechsler, W. (2011) The law and economics of the Estonian law on cultural autonomy for national minorities and of Russian national cultural autonomy in Estonia, Halduskultuur, 12(1), pp. 43-61.

Alenius, K. (2003) Ajan ihanteiden ja historian rasitteiden ristipaineissa: Viron etniset suhteet vuosina 1918-1925 [Under the Conflicting Pressures of the Ideals of the Era and the Burdens of History: Ethnic Relations in Estonia 1918-1925] (Rovaniemi: Pohjois-Suomen historiallinen yhdistys).

Alenius, K. (2004) Under the conflicting pressures of the ideals of the era and the burdens of history: ethnic relations in Estonia, 1918-1925, J ournal of Baltic Studies, 35(1), pp. 32-49.

Alenius, K. (2006) Unification with Sweden, autonomy, federal self-government? The dilemma of the Swedish minority of Estonia during the period between the world wars, Scandinavian J ournal of History, 31(3-4), pp. 308-327.

Alenius, K. (2007) The birth of cultural autonomy in Estonia: how, why, and for whom? J ournal of Baltic Studies, 38(4), pp. 445-462.

Aun, K. (1950) On the Spirit of the Estonian Minorities Law (Stockholm: Estonian Information Centre).

Bauböck, R. (2001) Territorial or cultural autonomy for national minorities? Österreichische Akademie der W issenschaften Forschungsstelle für Institutionellen Wandel und Europäische Integration (IWE)-Working Paper Series, 22, December.

Coakley, J . (1994) Approaches to the resolution of ethnic conflict: the strategy of non-territorial autonomy, International Political Science Review, 15(3), pp. 297-314.

Coakley, J . (2016) Introduction: dispersed minorities and non-territorial autonomy, Ethnopolitics, 15(1), pp. to be supplied.

Crols, D. (2005) Old and new minorities on the international chessboard: from League to Union, in D. J . Smith (Ed.), The Baltic States and their Region: New Europe or Old?, pp.185-209 (Amsterdam, Rodopi).

de Vries, A. (1930) Fünf J ahre deutsche Kulturselbstverwaltung, Revalsche Zeitung, 22 November. 
Eesti Vabariigi põhiseadus (1920), available online at: http://et.wikisource.org/wiki/Eesti_Vabariigi_p\%C3\%B5hiseadus_(1920)

Hiden, J . \& S mith D.J . (2006) Looking beyond the nation state: a Baltic vision for national minorities between the wars, J ournal of Contemporary History, 41(3), pp. 387-400.

Hooghe, L., Schakel, A.H. \& Marks, G. (2008) Appendix B: Country and regional scores, Regional and Federal Studies, 18(2-3), pp. 259-74.

Kriszán, A. (2000) The Hungarian minority protection system: a flexible approach to the adjudication of ethnic claims, J ournal of Ethnic and Migration Studies, 26(2), pp. 247-262.

Lagerspet, M. (2014) Cultural autonomy of national minorities in Estonia: the erosion of a promise, J ournal of Baltic Studies, 45(4), pp. 457-75

Laurits, K. (2008) Saksa kultuuromavalitsus Eesti Vabariigis 1925-1940 [The German Cultural SelfGovernment in the Republic of Estonia 1925-1940] (Tallinn: Rahvusarhiiv).

Nimni, E. (Ed.) (2005) National Cultural Autonomy and its Contemporary Critics (London: Routledge).

Osipov, A. (2013) Non-territorial autonomy during and after communism: in the wrong or right place?, J ournal on Ethnopolitics and Minority Issues in Europe, 12(1), pp.7-26.

Piirimäe, K. (2012) Federalism in the Baltic: interpretations of self-determination and sovereignty in Estonia in the first half of the twentieth century, East Central Europe, 39, pp. 237-265.

Poleshchuk, V. (2013) Changes in the Concept of National Cultural Autonomy in Estonia, in: E. Nimni, A. Osipov, D. J . S mith (Eds), The Challenge of Non-Territorial Autonomy: Theory and Practice, pp. 149-162 (Oxford, Bern, Berlin, Bruxelles, Frankfurt am Main, New York, Wien: Peter Lang Publishers).

Smith, D.J . (1999) Retracing Estonia's Russians: Mikhail Kurchinskii and inter-war cultural autonomy, Nationalities Papers, 27(3), pp. 455-474.

S mith, D.J . (2005) Non-territorial cultural autonomy as a Baltic contribution to Europe between the wars, in D. J . S mith (Ed.), The Baltic States and their Region: New Europe or Old?, pp. 211-226 (Amsterdam, Rodopi).

Smith, D.J . (2013a) Non-territorial autonomy and political community in contemporary central and eastern Europe, J ournal on Ethnopolitics and Minority Issues in Europe, 12(1), pp. 27-55.

Smith, D.J . (2013b) Challenges of non-territorial autonomy in contemporary central and eastern Europe, in: E. Nimni, A. Osipov, D. J . S mith (Eds), The Challenge of Non-Territorial Autonomy: Theory and Practice, pp. 117-32 (Oxford, Bern, Berlin, Bruxelles, Frankfurt am Main, New York, W ien: Peter Lang Publishers).

S mith, D.J . (2014) National Cultural Autonomy in Contemporary Estonia, in: L. Salat, S. Constantin, A. Osipov, I. Székely (Eds), Autonomy Arrangements around the World: A Collection of Well and Lesser Known Cases, pp. 299-316 (Cluj-Napoca: Romanian Institute for Research on National Minorities). 
S mith, D.J . \& Cordell, K. (Eds) (2008) Cultural Autonomy in Contemporary Europe (London and New York: Routledge).

S mith, D.J . \& Hiden, J . (2012) Ethnic Diversity and the Nation State: National Cultural Autonomy Revisited (London: Routledge).

Statistics Estonia (2011) Population 1881-2010, available online at: http://www.stat.ee/62931

Weiss-Wendt, A. (2008) Thanks to the Germans! J ewish cultural autonomy in interwar Estonia, East European J ewish Affairs, 38(1), pp. 89-104.

W.E. (1936) Zehn J ahre deutsche Kulturselbstverwaltung, Nation und Staat, 9(4), pp. 222-6. 